\title{
Quest for Tax Education in Non-Accounting Curriculum: A Malaysian Study
}

\author{
Ming Ling Lai ${ }^{1}$, Yaacob Zalilawati ${ }^{1}$, Mahat Mohd Amran ${ }^{1} \&$ Kwai Fatt Choong ${ }^{2}$ \\ ${ }^{1}$ Accounting Research Institute \& Faculty of Accountancy, Universiti Teknologi Mara, Malaysia \\ ${ }^{2}$ Faculty of Business and Accountancy, University of Malaya, Malaysia \\ Correspondence: Ming Ling Lai, Accounting Research Institute \& Faculty of Accountancy, Level 12, Menara \\ SAAS, 40450, Shah Alam, Selangor, D. E, Malaysia. Tel: 60-3-5544-4975. E-mail: \\ laimingling@salam.uitm.edu.my
}

Received: November 19, 2012 Accepted: December 16, 2012 Online Published: January 28, 2013

doi:10.5539/ass.v9n2p154 URL: http://dx.doi.org/10.5539/ass.v9n2p154

\begin{abstract}
This study aims (i) to ascertain the demand for tax education among Malaysian undergraduates from non-accounting disciplines; (ii) to examine the level of tax knowledge among non-accounting undergraduates; (iii) to identify the instructional methods to be used; and (iv) to determine the relevant tax topics to be covered in tax course for the non-accounting curriculum. A questionnaire was given to undergraduates from non-accounting disciplines in three public universities in Malaysia from the month of February to April 2011. Out of the 1,575 questionnaires distributed, 995 usable responses were received and analyzed. This survey found (i) majority of the respondents were in favor of tax education being introduced into non-accounting curriculum as an elective paper; (ii) about $44.9 \%$ had little tax knowledge; (iii) the most preferred methods of teaching taxation are case studies and face-to-face classroom learning; and (iv) the topics that the respondents would like to learn the most are personal taxation, tax planning for individual and basic concepts of taxation. The findings provided important insight in order to reform the current education policy, to introduce tax education formally in non-accounting curriculum, as tax education is the pillar that builds a tax literate society. This study could be seen as the first large-scale study conducted after the implementation of self-assessment tax system in Malaysia. Study on tax education from developing country like Malaysia is rare; hence, this study would fill a knowledge gap.
\end{abstract}

Keywords: higher education, non-accounting curriculum, undergraduate, Malaysia, tax education

\section{Introduction}

Since the year of assessment 2004, the Inland Revenue Board Malaysia had launched a self-assessment system for individual taxpayers. Under this system, the onus to assess tax liability rests on the taxpayers. Hence, to be tax compliant, taxpayers need to possess some basic knowledge on personal taxation. In particular, individual taxpayers need to have some knowledge on taxability of income, deductibility of expenses, entitlements, reliefs, rebates and exemptions, in order to compute tax liability correctly. The statistics from the Inland Revenue Board Malaysia showed that the number of tax audit cases has increased from 2005 to 2009 and the number of additional tax and penalties raised has also risen over the years (see Table 1). The statistics somewhat indicate that after the implementation of the self-assessment system, tax non-compliance and tax offences are on the rise. In view that not all citizens have any formal tax education in primary, secondary and tertiary levels, the concern is whether individual taxpayers have adequate tax knowledge to calculate tax liability correctly as well as to deal with tax audit.

Table 1. Tax audits (including of field audit and desk audit)

\begin{tabular}{llllll}
\hline & 2005 & 2006 & 2007 & 2008 & 2009 \\
\hline Number of tax audited cases settled & 7,204 & 6,741 & 279,175 & $1,052,939$ & $1,399,660$ \\
Amount of additional tax and penalty (RM million) & 635.40 & 692.68 & $1,410.57$ & $1,697.16$ & $3,054.95$ \\
\hline
\end{tabular}

Source: The IRBM, 2008, 2009

The renowned scientist, Albert Einstein (1879-1956) once asserted "the hardest thing in the world to understand is income tax." In line with this, several tax educators had argued that it is important to teach young people 
(future taxpayers) about taxation before they have to pay income tax, so that they will respect the tax system and understand the requirement of having to pay tax when they start working(Barjoyai, 1992; Furnham, 2005; Kasipillai, Norhani, \& Noor Afiza, 2003). However, in many higher learning institutions in the world, as well as in Malaysia, only accounting and some business management students are exposed to taxation at the tertiary level (Kasipillai, et al., 2003). For example, in one of the largest public universities in Malaysia, namely, Universiti Teknologi Mara (UiTM), out of twenty-four faculties, tax subjects are only taught to undergraduates from three faculties, i.e., Faculty of Accountancy, Faculty of Administrative Science and Policy Studies as well as Faculty of Computer and Mathematical Sciences. As a result, the majority of non-accounting undergraduates have little or no exposure to taxation as tax subject are not formally incorporated into non-accounting curriculum.

On the other hand, about four decades ago, an eminent accounting professor in the United States, Professor Sommerfeld asserted that taxation has become an education's orphan (Sommerfeld, 1966). He argued that universities should offer unique perspective on tax subject to students, and he was of the opinion that taxation should be taught rather than just practiced and learned. More than twenty years ago, Malaysian tax scholars such as Barjoyai (1992) (1992) and Ho (1992) had called for tax education to be incorporated in all disciplines. Barjoyai (1992) argued that knowledge of taxation is probably more important than knowledge of geography or geometry; as taxation is the universal knowledge needed by each citizen who has the potential to pay income tax one day. He asserted that all undergraduates needed to be equipped with sufficient tax knowledge at school or tertiary levels in order for them to be tax literate. In South Africa, Oberholzer and Stack (2009) also called for a comprehensive, widely based communication and education for taxpayers and potential taxpayers to close the tax gap and tax non-compliance. Unfortunately, to date, with the exception of a few countries (for example, Canada, Japan and United States), the call to incorporate tax subject into non-accounting curriculum has not been observed.

Pragmatically, non-accounting undergraduates need to be exposed to tax education, as they are future taxpayers. However, at the time of study, little is known about non-accounting undergraduates' understanding of taxation. With the exception of studies conducted by Craner and Lymer (1999), Miller and Woods (2000), Schwartz and Stout (2001), Hite and Hasseldine (2001), Juchau and Neale (2001), Furnham (2005) as well as Tan and Veal (2005), there is a dearth of literature on tax education even in the developed countries. In the Malaysian context, except for Kasipillai et al. (2003) and Anis Barieyah and Lai (2009) who in their studies attempted to examine the understanding of taxation among the Malaysian undergraduates and working adults, little study has been conducted to examine tax education in order to develop a tax education blueprint for non-accounting curriculum. Hence, the lack of empirical study is the motivation for this study.

\section{Research Objectives}

This study aims i) to find out the demand for tax education among the Malaysian undergraduates from non-accounting disciplines; ii) to examine the level of tax knowledge among non-accounting undergraduates; iii) to identify the suitable instructional methods; and iv) to determine the relevant tax topics to be covered in tax course for the non-accounting curriculum.

\section{Literature Review}

The backbone in the development of the tax culture is tax education. Tax education may be defined as a general introduction to concepts and principles of taxation covering personal, business and corporation taxation, tax administration, assessment and appeal, basic tax planning for individuals and businesses. Hite and Hasseldine (2003) asserted that the United States arguably has one of the most developed tax education systems in the world. Notably, the American Taxation Association formed a 'Teaching Resources Committee' to support and assist tax educators in teaching and doing tax research. In addition, the American Tax Authority, the Internal Revenue Service (IRS) has created an educational site called 'Understanding Taxes' for high school students and other learners (IRS, 2005). The IRS developed interactive educational kits to include lessons on the nation's history of taxation, tax return preparation and the economics of taxation to help students understand the basic, rationale, nature and consequences of taxes.

\subsection{Objectives of Tax Education in Non-Accounting Curriculum}

The primary objective of tax education is to break the vicious circle and create awareness that taxation is not only a legal obligation but also the duty of each citizen. The secondary objective of incorporating tax education in non-accounting curriculum is to improve tax literacy of future and potential taxpayers. In Japan, knowing the importance of tax education, the Japanese government has used tax education as one of the measures to enhance tax compliance; the Japanese government has introduced tax education to students in school because students are 
the future taxpayers (Sarker, 2003). It was reported that countries with high level of tax compliance such as Canada, the United States, Switzerland and New Zealand had included tax development programs to prepare students for adult life at the early stage of education (CIAT, 2011).

Prior studies found that tax education may influence one's attitude towards taxation and tax compliance behaviors (for example,Barjoyai, 1992; Eriksen \& Fallan, 1996; Kasipillai, et al., 2003). Tax education enables people to understand the tax system better. Eriksen and Fallan (1996) as well as Kasipillai et al. (2003) found that with reasonable understanding of the tax laws, individuals are more willing to respect the tax system, thus they become more tax compliant. With basic tax education, an individual is able to comply with tax laws. After surveying the Malaysian undergraduates, Kasipillai et al. (2003) found that tax education influenced the attitudes and mindsets of these undergraduates towards tax avoidance and evasion. They found that tax knowledge improved an individual's tax ethics behavior. Kasipillai et al. (2003) suggested that it is important for all undergraduates (future taxpayers) to have sufficient tax knowledge in order to reduce their tendencies of non-compliance. Amrizah and Nero (2005) surveyed the tax knowledge of working adults (the salaried individuals in East Malaysia); they found that the survey respondents had an average knowledge of personal taxation. Meanwhile, Loo and Ho (2005) examined white-collar salaried individuals' tax knowledge in Malacca (a state located at the centre region of Malaysia). They found that the survey respondents did not possess sufficient tax knowledge pertaining to personal taxation even though they had tertiary education. Loo and Ho (2005) found that the majority of salaried individuals surveyed were unable to identify the correct year of which a given income is taxable. On top of this, they were not fully aware of personal tax reliefs, rebates, entitlements and exemptions. It raised the concern that majority of the Malaysian salaried individuals surveyed might have filed incorrect tax returns in this era of self-assessment system. After surveying 450 working adults who were pursuing off-campus non-accounting program in one of the public universities in Malaysia, Anis Barieyah and Lai (2009) found $64 \%$ of the Malaysian working adults were keen to learn about taxation.

\subsection{A Suitable Phase in the Education Cycle to Introduce Tax in Non-Accounting Curriculum}

In South Africa, Oberholzer and Nel (2006) argued that in considering the percentage of students aged 5 to 24 attending an educational institution are the taxpayers of the future, implementing tax education in school or early secondary level would have the best chance of success. This would ensure that a large percentage of future taxpayers would have the opportunity to receive some form of tax training. However, in the United States, Furnham (2005) examined children ranging from 10 to 15 years old; he found that the adolescents are unable to fully comprehend the nature and purpose of taxation. Furnham (2005) then argued that at the tertiary level, students would have a broader educational view on taxation, hence, they could comprehend tax subject better. In line with this, Norazah (2006) found among the Malaysian academics surveyed believed that students should be exposed to tax education at the tertiary level; because tax knowledge is too advanced and specialized to be included in primary and secondary curricula.

\subsection{The Component of Good Curriculum}

Flesher and Rescho (1986) argued that a basic tax course required students to memorize rules and methods of calculations, and that learning could be achieved effectively if tax concepts were embodied in the course along with the tax rules and regulations. Gore and Wong (1998) suggested that tax skills (procedural knowledge) should be taught, as opposed to detailed tax rules and facts (declarative knowledge). Procedural knowledge is about "knowing how" (e.g., knowing how to compute a personal income tax), as opposed to 'declarative knowledge', which is about 'knowing that' (e.g., knowing that salary income is taxable). Gore and Wong(1998) proposed that when teaching tax classes, educators should consider the following four steps: (1) Instruction is organized around specific tax skills; (2) A task analysis is completed for each skill; (3) Instruction is example-based; and (4) Learners are given practice on holistic real-world problems. The renowned scientist Thomas Edison once asserted that 'practice without theory is empty, while theory without practice is like being blind'. Hence, for effective learning and teaching, it is important to maintain a link between declarative and procedural knowledge, so that tax knowledge acquired (body of knowledge) can be practiced through solving real problem or case studies.

In respect to the extent and level of technical details that should be covered in a tax course, Jones and Duncan (1995) suggested that the nature of the concepts, their usefulness to students, as well as whether the concepts add to their understanding of the deep structure of the tax laws, should be used as guidelines. Whilst, Nichols, Everett and Boley (1999) asserted that when "any new tax legislation is passed, the challenge facing an educator is that the new tax law must be learned and understood" (Nichols, et al., 1999, p. 118). In essence, if certain regulations in the tax laws are frequently changed, the curriculum should omit them, but common and key tax 
concepts and issues should be included. Pragmatically, the basis of selection of coverage in tax subject should be based on the probability of use by students, to cover tax topics that most likely to be encountered and applied by a majority of the students (future taxpayers).

\subsection{Tax Instructional Method}

With regards to the method to imparting tax education, Jones and Duncan (1995) recommended a new approach to teach tax subject. They outlined that tax education must consist of the following three key principles. Firstly, students should recognize that tax law is an integrated component of a complex business environment. Secondly, students need to comprehend the body of tax law as an organic whole and not as a fragmented collection of isolated rules and regulations. They should learn how the general rules apply to all taxpaying entities before they are taught how the law applies differentially to certain taxpayers. The third principle is that students who fully grasp fundamental concepts will have a permanent frame of reference into which they can integrate the constant changes in the technicalities of tax law. Several studies found the use of case studies modifies students' approaches to learning (Boyce, Willliams, Kelly, \& Yee, 2001; Weil, Oyelere, Yeoh, \& Farer, 2001; Weinstein \& Bloom, 1998). In particular, Weinstein and Bloom (1998) found that the case study method better facilitates the learning of taxation; as the inclusion of case study challenges students to think about the implications of the law rather than simply memorizing rules. Whilst, Tan and Laswad (2011) asserted that tertiary students have the ability to adapt to different learning styles and teaching methods. They argued that incorporating a diversity of teaching and learning approaches will provide students with the opportunity to reflect and apply what they have learned to various tax situations.

To sum up, a review of past tax literature provides the insights that when designing a tax curriculum, a variety of approaches and guidelines could be used. A tax curriculum for non-accounting students informs learners about taxation, but does not necessarily focus on in-depth knowledge of the subject. In essence, non-accounting undergraduates must be taught the 'Whys of taxes' that examines the theory and history behind Malaysian taxes, and the 'Hows of taxes' that provide tax application. The breadth and depth of tax principles and theory should be applicable and appropriate; and non-accounting undergraduates should be exposed to the tax topics, which are practical to instill their interests to learn. The course material must be simple, practical, up-to-date, and concise. The text should also be in an easy-to-teach format so that tax educators could impart basic tax knowledge to learners effectively.

\section{Research Method}

A self-administered survey was designed to collect the data. The questionnaire was divided into six parts. Part 1 gathered respondents' demographic information. Part 2 solicited respondents' attitude toward taxation. In Part 3, eight questions were designed to assess respondents' knowledge pertaining to basic personal tax knowledge. Part 4 solicited respondents' desire to learn taxation during the course of the study. Part 5 gathered respondents' preference on the instructional methods that should be used in tax education. Six methods were chosen because understanding and applying tax laws to various chargeable persons requires an interactive mode of teaching via internet involving case studies, simulation and discussion. Part 6 solicited respondents' opinion on the relevant topics that should be taught if tax subject is introduced. Respondents were asked to rank the nine relevant tax topics related to personal income tax.

The population of interest of this study was non-accounting undergraduates enrolled in public universities in Malaysia in 2011. With the help of two research assistants, 1,575 questionnaires were distributed to non-accounting students in three largest public universities in Malaysia from the month of February to April 2011. The research assistants were briefed and they approached students outside the lecture halls, in the cafeteria and the areas surrounding the library. As the responses were voluntarily; out of the 1,575 questionnaires distributed, 995 usable questionnaires were collected and analyzed.

\section{The Findings}

The respondents' profile shows out of the 995 respondents, more than two thirds $(67.7 \%)$ were female students, only $32.3 \%$ were males. The respondents' profile somewhat reflected the reality of the Malaysian universities where the ratio of female students to male students is 70:30.

\subsection{Non-Accounting Undergraduates' Attitude towards Taxation and Tax Knowledge}

Five questions were designed to assess respondents' attitude towards taxation. The survey (see Table 2) found most respondents had positive attitudes towards paying taxes and believed that paying taxes is good for our society. 
Table 2. Attitude towards taxation

\begin{tabular}{|c|c|c|c|c|c|c|c|}
\hline Statement & $\mathrm{SD} \%$ & $\begin{array}{c}\mathrm{MD} \\
\%\end{array}$ & $\begin{array}{l}\mathrm{N} \\
\%\end{array}$ & $\begin{array}{c}\text { MA } \\
\%\end{array}$ & $\begin{array}{c}\mathrm{SA} \\
\%\end{array}$ & Mean* & $\begin{array}{l}\text { Std } \\
\text { Dev }\end{array}$ \\
\hline 1) Paying tax is the right thing to do & 5.2 & 8.1 & 39.4 & 34.0 & 13.3 & 3.42 & 0.993 \\
\hline $\begin{array}{l}\text { 2) Paying tax is a responsibility that should be willingly } \\
\text { accepted by all Malaysians }\end{array}$ & 3.6 & 9.5 & 35.8 & 38.4 & 12.7 & 3.47 & 0.954 \\
\hline $\begin{array}{l}\text { 3) I believe paying tax is good for our society, and } \\
\text { therefore it is good for each of us. }\end{array}$ & 4.3 & 11.0 & 35.4 & 38.4 & 11.0 & 3.41 & 0.969 \\
\hline 4) It is disappointing that some people do not pay their tax & 3.4 & 8.8 & 31.9 & 35.7 & 20.2 & 3.60 & 1.012 \\
\hline $\begin{array}{l}\text { 5) It makes it difficult to govern the country when people } \\
\text { do not pay their tax }\end{array}$ & 4.8 & 6.6 & 28.6 & 38.9 & 21.9 & 3.66 & 1.042 \\
\hline
\end{tabular}

* Note: All mean values are on a 5-point scale, anchored on 1=SD (Strongly Disagree); 2= MD (Moderately Disagree); 3=N (Neutral); 4=MA (Moderately Agree) and 5=SA (Strongly Agree). All mean values were significant at $p<0.001$.

In turn, eight questions were designed to gauge the respondents' tax knowledge pertaining to personal relief, rebates, exemptions and entitlements. The results are presented in Table 3. The survey found only $8.9 \%$ of the respondents knew that as of assessment year 2010, an individual taxpayer is entitled to claim personal relief of RM9,000. In respect of relief for parents' medical expense of RM5,000, only $24.5 \%$ of the respondents aware of this claim. In order to encourage citizens to be computer literate, starting from year of assessment 2010, a relief of RM500 on broadband Internet subscription was given; however, only $14.1 \%$ knew about it. The findings also indicate that majority of the respondents did not know that they were entitled to claim relief on purchase of books and sports equipment. To further examine the tax knowledge of the respondents, knowledge score of Eriksen and Fallan (1996) was adapted and used in this study. Responses with 'Yes' answers were given a score of 3 (well informed), those who answered 'No' were given a score of 1 (misinformed) and those answered 'Not sure' received a score of 2 (un-informed). The results as presented in Table 4 show that merely 2.4\% (24/995) obtained full marks and $16.3 \%(162 / 995)$ of the respondents obtained a minimum score of 8 marks. In turn, based on tax knowledge scores, the respondents were categorized into three groups namely, high, medium and low level of tax knowledge. The result shows that only $10.67 \%$ of the respondents possessed high level of tax knowledge, $44.5 \%$ and $44.9 \%$ had medium and low level of basic tax knowledge (see Table 5). The results somewhat indicate that the majority of respondents did not stay abreast with tax knowledge as they were not formally exposed to tax.

Table 3. Respondents' knowledge about personal taxation

\begin{tabular}{|c|c|c|c|c|}
\hline & Statement & $\begin{array}{c}\text { Yes } \\
\text { Frequency }\end{array}$ & $\begin{array}{l}\text { No } \\
\text { Frequency }\end{array}$ & $\begin{array}{l}\text { Not sure } \\
\text { Frequency }\end{array}$ \\
\hline 1 & $\begin{array}{l}\text { Do you know that starting from year of assessment 2010; individual } \\
\text { taxpayer is entitled to a personal relief of RM } 9,000 \text { ? }\end{array}$ & $\begin{array}{c}89 \\
(8.9)\end{array}$ & $\begin{array}{c}411 \\
(41.3)\end{array}$ & $\begin{array}{c}495 \\
(49.7)\end{array}$ \\
\hline 2 & $\begin{array}{l}\text { Do you know that individual taxpayer is entitled for a further sum of } \\
\text { RM6, } 000 \text { if he or she is a disabled person? }\end{array}$ & $\begin{array}{c}137 \\
(13.8)\end{array}$ & $\begin{array}{c}401 \\
(40.3)\end{array}$ & $\begin{array}{c}457 \\
(45.9)\end{array}$ \\
\hline 3 & Do you know that relief for parents' medical expenses is RM5, $000 ?$ & $\begin{array}{c}244 \\
(24.5)\end{array}$ & $\begin{array}{c}387 \\
(38.9)\end{array}$ & $\begin{array}{c}364 \\
(36.6)\end{array}$ \\
\hline 4 & $\begin{array}{l}\text { Do you know that relief in respect of complete medical examination } \\
\text { expenses on the taxpayer, the spouse and the child is RM500? }\end{array}$ & $\begin{array}{c}189 \\
(19.0)\end{array}$ & $\begin{array}{c}453 \\
(45.5)\end{array}$ & $\begin{array}{c}353 \\
(35.5)\end{array}$ \\
\hline 5 & $\begin{array}{l}\text { Do you know that relief on education fees in technical, vocational, } \\
\text { industrial, scientific or technological skills at tertiary level in any } \\
\text { institution or professional body recognized by the government is } \\
\text { RM5, 000? }\end{array}$ & $\begin{array}{c}175 \\
(17.6)\end{array}$ & $\begin{array}{c}451 \\
(45.3)\end{array}$ & $\begin{array}{c}369 \\
(37.1)\end{array}$ \\
\hline 6 & $\begin{array}{l}\text { Do you know that starting from Year of Assessment } 2010 \text { until 2011, } \\
\text { a relief on broadband Internet subscription is RM500? }\end{array}$ & $\begin{array}{c}140 \\
(14.1)\end{array}$ & $\begin{array}{c}458 \\
(46.0)\end{array}$ & $\begin{array}{c}397 \\
(39.9)\end{array}$ \\
\hline 7 & $\begin{array}{l}\text { Do you know that relief on the purchase of books, magazines and } \\
\text { journals is RM1, } 000 \text { ? }\end{array}$ & $\begin{array}{c}243 \\
(24.4)\end{array}$ & $\begin{array}{c}427 \\
(42.9)\end{array}$ & $\begin{array}{c}325 \\
(32.7)\end{array}$ \\
\hline 8 & $\begin{array}{l}\text { Do you know that relief on the purchase of sports equipment for any } \\
\text { sport activities under Sports Development Act } 1997 \text { is RM300? }\end{array}$ & $\begin{array}{c}121 \\
(12.2)\end{array}$ & $\begin{array}{c}457 \\
(45.9)\end{array}$ & $\begin{array}{c}417 \\
(41.9)\end{array}$ \\
\hline
\end{tabular}


Table 4. Summary tax knowledge scores of the respondents

\begin{tabular}{ccc}
\hline Score & Frequency & Percentage (\%) \\
\hline 8.00 & 162 & 16.3 \\
9.00 & 29 & 2.9 \\
10.00 & 51 & 5.1 \\
11.00 & 56 & 5.6 \\
12.00 & 57 & 5.7 \\
13.00 & 39 & 3.9 \\
14.00 & 53 & 5.3 \\
15.00 & 45 & 4.5 \\
16.00 & 229 & 23.0 \\
17.00 & 71 & 7.1 \\
18.00 & 57 & 5.7 \\
19.00 & 41 & 4.1 \\
20.00 & 43 & 4.3 \\
21.00 & 17 & 1.7 \\
22.00 & 12 & 1.2 \\
23.00 & 9 & 0.9 \\
24.00 & 24 & 2.4 \\
\hline
\end{tabular}

Table 5. Range of scores

\begin{tabular}{cccc}
\hline Level of tax knowledge & Range of Score & Frequency & Percentage \\
\hline Low & $8-13$ & 447 & 44.9 \\
Medium & $14-19$ & 443 & 44.5 \\
High & $20-24$ & 105 & 10.6 \\
\hline
\end{tabular}

\subsection{Quest to Learn Tax in the Course of Study}

When asked whether tax subject should be introduced at the non-accounting faculty, Table 6 shows majority of the respondents were in favor (with mean score of 3.34 on a five-point likert scale, significant at $p<0.001$ ). The finding suggests that there is a general consensus among them that tax subject should be introduced at tertiary level. Nevertheless, they also indicated that tax subject should be offered as an elective rather than a compulsory subject (with mean score of 3.21 on a five-point likert scale, significant at $p<0.001$ ). This could be due to the fact that there are too many core subjects that they need to learn in the course of study; thus leaving no room to incorporate tax subject as a compulsory subject. Overall, the findings indicate that majority of the respondents agreed that tax subject should be introduced in non-accounting curriculum.

Table 6. Desire to learn taxation in the course of your study

\begin{tabular}{llccc}
\hline \multicolumn{1}{c}{ Statement } & Mean & $\begin{array}{c}\text { Standard } \\
\text { Deviation }\end{array}$ & t-test & $p$-value \\
\hline 1. I like to learn about taxation & $3.284^{* * *}$ & 0.998 & 6.719 & 0.000 \\
2. $\begin{array}{l}\text { Tax subject should be introduced in the course that I am } \\
\text { pursuing now }\end{array}$ & $3.341^{* * *}$ & 1.002 & 1.362 & 0.173 \\
$\begin{array}{l}\text { 3. Tax subject should be introduced as a compulsory subject } \\
\text { in the course that I am pursuing now. }\end{array}$ & $3.055^{* *}$ & 1.006 & -5.659 & 0.000 \\
4. $\begin{array}{l}\text { Tax subject should be introduced as an elective subject in } \\
\text { the course that I am pursuing now. }\end{array}$ & $3.208^{* * *}$ & 1.009 & 2.054 & 0.040 \\
\hline
\end{tabular}

*Significant at $p<0.1$; * Significant at $p<0.05$; ** Significant at $p<0.001$ 


\subsection{Tax Instructional Method}

The respondents were asked which tax instruction method would they preferred if tax course was introduced in non-accounting curriculum. The answer is found in Table 7 where the preferred method of learning tax is using case studies (with mean score of 3.31 on a 5-point likert scale, significant at $p<0.001$ ). As tax subject requires understanding, interpretation and application of tax laws, with tax case studies students would be able to understand tax policy and practice better. This finding somewhat supported the study of Weinstein and Bloom (1998) that using case studies to encourage students to explore alternatives that would provide useful information for financial and tax planning. Case studies can be presented either in a stand-alone fashion or as part of an integrated problem that ends with the completion of an individual personal tax return. The second preferred method is face-to-face classroom learning (mean score 3.28 on a five point scale, significant at $p<0.001$ ); the plausible explanation is face to face method enable students to ask question and interact directly with the instructor; thus, the acquisition and transfer of tax skills can be done through interaction. The least preferred method of is using e-learning (with mean of 2.86 on a five-point likert scale, significant at $p<0.001$ ).

Table 7. Preferred tax instructional methods

\begin{tabular}{|c|c|c|c|c|c|}
\hline Statement & Mean* & $\begin{array}{l}\text { Standard } \\
\text { Deviation }\end{array}$ & t-test & $p$-value & Ranking \\
\hline Tax subject should involve tax case studies. & 3.311 & 1.047 & 9.263 & 0.000 & 1 \\
\hline $\begin{array}{l}\text { Tax subject should involve classroom face- to-face } \\
\text { learning. }\end{array}$ & 3.284 & 0.998 & 8.988 & 0.000 & 2 \\
\hline Tax subject should involve e-tax discussion. & 3.208 & 1.009 & 6.498 & 0.000 & 3 \\
\hline Tax subject should involve tax simulation. & 3.210 & 0.980 & 6.759 & 0.000 & 4 \\
\hline Tax subject should involve e-tax quiz. & 3.055 & 1.006 & 1.733 & 0.000 & 5 \\
\hline $\begin{array}{l}\text { Tax subject should involve non face to face tutorial } \\
\text { through e-learning. }\end{array}$ & 2.866 & 1.002 & -4.205 & 0.000 & 6 \\
\hline
\end{tabular}

*All means were measured on 5-point likert scale and significant at $p<0.001$

\subsection{Tax Topics That Non-Accounting Undergraduates Like to Learn the Most}

The results (see Table 8) show three tax topics that the respondents would like to learn the most are 'Personal Taxation', 'Tax Planning for the Individual' and 'Introduction to Malaysian Taxation System' with the mean score of 3.59, 3.58 and 3.52 respectively (significant at $p<0.001$ ). Surprisingly, the respondents wished to learn more about 'Goods and Services Tax', even though 'Goods and Services Tax' has not been implemented in Malaysia. The plausible explanation is that the Malaysian government has long announced the implementation of 'Good and Services Tax' in the near future; the extensive publicity in the mass media might have aroused respondents' interest and curiosity. In turn, the other tax topics these non-accounting undergraduates desired to learn were 'Small Business Taxation', 'Tax Planning for Small Businesses', 'Real Property Tax' and 'Partnership Taxation'.

Table 8. Tax topics that non-accounting undergraduates like to learn the most

\begin{tabular}{|c|c|c|c|c|}
\hline Statement & Mean * & Standard Deviation & t-test & \#Ranking \\
\hline 1. Personal Taxation. & 3.589 & 0.981 & 18.968 & 1 \\
\hline 2. Tax Planning for the Individual. & 3.588 & 0.980 & 18.998 & 2 \\
\hline 3. Introduction to Malaysian Taxation System & 3.515 & 0.994 & 16.326 & 3 \\
\hline Sales and Service Tax or Goods and Services Tax. & 3.472 & 0.964 & 15.454 & 4 \\
\hline Tax Planning for Small Businesses. & 3.441 & 0.978 & 14.226 & 5 \\
\hline Malaysian Tax Administration System. & 3.424 & 0.966 & 13.855 & 6 \\
\hline Small Business Taxation. & 3.401 & 0.949 & 13.332 & 7 \\
\hline Real Property Gains Tax. & 3.344 & 0.947 & 11.456 & 8 \\
\hline $9 \quad$ Partnership Taxation. & 3.306 & 0.945 & 10.233 & 9 \\
\hline
\end{tabular}

* Significant at $\mathrm{p}<0 ; * *$ Significant at $\mathrm{P}<0.05 ; * * *$ Significant at $\mathrm{p}<0.001$

\# The ranking is based on the highest mean values. 


\section{Conclusion}

This study provides some insights on the quest to learn about taxation among non-accounting undergraduates. At the time of study, although self-assessment tax system has been implemented for seven years on salaried individuals, the survey found that the respondents' level of tax knowledge was considerably low. The plausible explanation could be that non-accounting undergraduates had never received formal tax education in the course of study. Nonetheless, it is encouraging to find that majority of the undergraduates surveyed desired to learn about taxation and they indicated that the most appropriate time for tax education is at the tertiary level. As undergraduates are future or potential taxpayers; hence, introducing tax education at the tertiary level should have the best chance of success. This study also discovered the most suitable tax topics to be introduced from the learners' perspective.

The limitations of this study are, firstly, it was a cross-sectional study; hence the respondents' views may change over time. Secondly, the data in this study was collected from three public universities in Malaysia and therefore may not be representative of students in other universities either in Malaysia or overseas. Nonetheless, this study has the merits as it is current and provides important insights to introduce tax as a curricular subject in non-accounting programs, in the era of self-assessment tax system. Specific strategy and collective effort must be taken by the Ministry of Higher Education and the relevant authorities to formulate a tax education framework for the non-accounting curriculum. To kick start tax education on all discipline at tertiary levels in Malaysia, the approval and endorsement from the Ministry of Higher Education need to be obtained, and a tax education blueprint need to be developed in due course.

To sum up, tax education is the most powerful tool to transform citizen's mindset and action. If issues related to health, environment and nutrition, road safety, civic education and education on social responsibility etc are included in the education system, then, it is recommended that tax subject is to be taught and learned in all disciplines as tax education is the foundation in building a tax literate society.

\section{Acknowledgments}

The earlier version was presented at the 13th Asian Academic Accounting Association annual conference at Kyoto University, 9-12 November, 2012. The authors thank the funding from Fundamental Research Grant Scheme, Research Management Institute, Universiti Teknologi MARA and Ministry of Higher Education, Malaysia. Ref: 600-RMI/SSP/FRGS 5/3/Fsp (14/2009)

\section{References}

Amrizah, K., \& Nero, M. (2005). Tax literacy adn tax awareness of salaried individuals in Sabah and Sarawak. Journal of Financial Reporting and Accounting, 3(1), 71-89. http://dx.doi.org/10.1108/19852510580000338

Anis Barieyah, M. B., \& Lai, M. L. (2009). Introducing Tax Education in Non-Accounting Curriculum in Higher Education: Survey Evidence. Journal of Financial Reporting \& Accounting, 7(1), 37-51. http://dx.doi.org/10.1108/19852510980000640

Barjoyai, B. (1992). Tax Illiteracy in Malaysia: Problems and Solution. Journal of School of Accountancy, MARA Institute of Technology, 11(2), 6-35.

Boyce, G., Willliams, S., Kelly, A., \& Yee, H. (2001). Fostering deep and elaborative learning and generic(soft) skill development: the strategic use of case studies in accounitng education. Accounting Education, 10(137-60). http://dx.doi.org/10.1080/09639280121889

CIAT. (2011). Tax Thematic Series. (13 July 2011). Retrieved from http://www.ciat.org/images/documents/bibiloleca/series/thematic_series13.pdf

Craner, J., \& Lymer, A. (1999). Tax education in the UK: a survey of tax courses in undergraduate accounting degrees. Accounting Education, 8(2), 127-156. http://dx.doi.org/10.1080/096392899330973

Eriksen, K., \& Fallan, L. (1996). Tax knowledge and attitudes towards taxation: A report on quasi-experiment. Journal of Economic Psychology, 17, 387-402. http://dx.doi.org/10.1016/0167-4870(96)00015-3

Flesher, T. K., \& Rescho, J. A. (1986). Tax concepts and their importance in the undergraduates curriculum. Journal of Accounting Education, 4, 55-68. http://dx.doi.org/10.1016/0748-5751(86)90023-0

Furnham, A. (2005). Understanding the meaning of tax: young peoples' knowledge of the principles of taxation. The Journal of socio-Economics, 34, 703-713. http://dx.doi.org/10.1016/j.socec.2005.07.014

Gore, R., \& Wong, O. W. B. (1998). The acquisition and transfer of tax skills. The Journal of American Taxation 
Association, 20(2), 117-126.

Hite, P. A., \& Hasseldine, J. (2003). Tax practitioner credentials and the incidence of IRS audit adjustments. Accounting Horizon, 17(1), 1-14. http://dx.doi.org/10.2308/acch.2003.17.1.1

Hite, P., \& Hasseldine, J. (2001). A primer on tax education in the United States of America. Accounting Education, 10(1), 3-13. http://dx.doi.org/10.1080/09639280110034734

Ho, J. K. (1992). An overview of tax education requirements. ACCAMADIA, Journal of Faculty of Accountancy, University Technology Mara, 2(43-45).

IRS. (2005). Understanding taxes. Retrieved December 23, 2005, from http://www.irs.gov/app/understandingTaxes/jsp/s_student_home.jsp

John, S. M., \& Duncan, W. A. (1995). Teaching the introductory tax course: a new paradigm. The Journal of American Taxation Association, 17, 95-103.

Juchau, R., \& Neale, R. (2001). Taxation in Australian undergraduate accounting courses: a review and case note. Accounting Education, 10(1), 27-36. http://dx.doi.org/10.1080/09639280110034752

Kasipillai, J., Norhani, A., \& Noor Afiza, A. (2003). The influence of education on tax avoidance and tax evasion. Journal of Tax Research, 1(2), 134-146.

Loo, E. C., \& Ho, J. K. (2005). Competency of Malaysian salaried individuals in relation to tax compliacne under self-assessment. Journal of Tax Research, 3(1), 45-62.

Miller, A. M., \& Woods, C. M. (2000). Undergraduate Tax Education: A Comparison of Educators' and Employers' Perceptions in the UK. Accounting Education, 9(3), 223-241. http://dx.doi.org/10.1080/09639280010017202

Nichols, N. B., Everett, J. O., \& Boley, R. (1999). Instructional resources for tax education: communicating the complexities of capital gains for individuals after the 1997 and 1998 tax acts. Accounting Education, 14(1), 117-143.

Norazah, M. A. (2006). The self-assessment tax system: the perception of academicians. Unpublished Master dissertation, Universiti Teknologi Mara, Shah Alam.

Oberholzer, R., \& Nel, M. (2006). The road to an improved tax curriculum in South African schools. Education as Change, 10(1), 105-120. http://dx.doi.org/10.1080/16823200609487132

Oberholzer, R., \& Stack, E. M. (2009). Perception of taxation: a comprehensive study of different individual taxpayers in South Africa. Journal of Public Administration, 44, 737-755.

Sarker, T. K. (2003). Improving Tax Compliance in Developing Countries via Self-Assessment Systems - What Could Bangladesh Learn from Japan? Asia-Pacific Tax Bulletin, 9(6), 1-34.

Schwartz, B. N., \& Stout, D., E. (2001). A comparison of practitioner and educator opinions on tax education requirement for undergraduate accounting majors. Issues in Accounting Education, 112-126.

Sommerfeld, R. M. (1966). Taxation: Education's Orphan. The Journal of Accountancy, December, 38-44.

Tan, L. M., \& Lastwad, F. (2011). Exploring the impact of students' learning style on performance in taxation. Journal of the Australasian Tax Teachers Association, 6(1), 152-169.

Tan, L. M., \& Veal, J. (2005). Tax knowledge for undergraduate accounting majors: conceptual V. techical. Journal of Tax Research, 3(1), 28-44.

The IRBM. (2008). Annual Report, the Inland Revenue Board Malaysia.

The IRBM. (2009). Annual Report, the Inland Revenue Board Malaysia.

Weil, S., Oyelere, P., Yeoh, J., \& Farer, C. (2001). A study of students' perceptions of the usefulness of case studies for development of Finance and accounting related skills and knowledge. Accounting Education, 10(2), 123-146. http://dx.doi.org/10.1080/09639280110081642

Weinstein, G. P., \& Bloom, R. (1998). Towards an integrated tax course: a mutual funds case study. Journal of Accounting Education, 16, 315-334. http://dx.doi.org/10.1016/S0748-5751(98)00014-1 